\title{
Catalytic Co-Pyrolysis of Palm Oil Empty Fruit Bunch and Coal into Liquid Oil
}

\author{
Sunarno*, Ronna Puspita Sari, Tifanny Frimacia, Silvia Reni Yenti, Panca Setia Utama, \\ Edy Saputra
}

\author{
Chemical Engineering Department, Riau University, Kampus Bina Widya KM 12,5 Pekanbaru 28293 Indonesia
}

\begin{abstract}
The decline in fossil fuel sources has prompted research into finding renewable fuels. One of environmentally friendly energy sources with high efficiency is by producing liquid oil from palm oil empty fruit bunch (EFB) and coal. Pre-treatment of empty fruit bunches using $\mathrm{NaOH}$ and various concentrations of $\mathrm{H}_{2} \mathrm{O}_{2}$, various ratios of $\mathrm{EFB} /$ coal, the ratio of $\mathrm{CaO}$ catalyst, chemical and physical characteristics were studied to produce the better liquid oil yield. The $\mathrm{H}_{2} \mathrm{O}_{2}$ concentrations are $0 \%, 1 \%, 2 \%$, and $3 \%$. The ratios of EFB/coal (R) are $0 / 100,25 / 75,50 / 50$, and $75 / 25$. The ratios of catalyst $\mathrm{CaO} / \mathrm{raw}$ material are $0 \%, 3 \%, 6 \%$, and $9 \%$. It ran at $400{ }^{\circ} \mathrm{C}$ with $100 \mathrm{~mL} / \mathrm{min}$ nitrogen gas flowing during one hour. The results showed that adding sodium hydroxide and hydrogen peroxide in the EFB pre-treatment increased the liquid oil yield. With an increase in the EFB/coal ratio, the liquid oil yield increased. Co-pyrolysis treated EFB and Coal with a ratio of $75: 25$ produced $32 \%$ liquid oil yield, but the liquid oil yield decreased to $19 \%$ with the addition of $9 \%$ CaO catalyst. However, the addition of $\mathrm{CaO}$ catalyst reduces the acidity and increases the calorific value of the liquid oil.
\end{abstract}

Keywords: coal, $\mathrm{CaO}$ catalyst, co-pyrolysis, empty fruit bunches, liquid oil

Article history: Received: $22^{\text {nd }}$ Oct 2021; Revised: $26^{\text {th }}$ Dec 2021; Accepted: $15^{\text {th }}$ January 2022; Available online: $3^{\text {rd }}$ Feb 2022

How to cite this article: Sunarno, S., Sari, R.P., Frimacia, T., Yenti, S.R., Utama, P.S., Saputra, E. (2022) Catalytic Co-Pyrolysis of Palm Oil Empty Fruit Bunch and Coal into Liquid Oil. International Journal of Renewable Energy Development, 11(2), 463-469 https://doi.org/10.14710/ijred.2022.42193

\section{Introduction}

The rapid development of the automotive industry has led to an increase in the demand for transportation fuels (Payormhorm et al. 2013; Sunarno et al. 2018). Until now, petroleum is still a dominant transportation fuel (Liu et al. 2014). Petroleum reserves are currently dwindling with the increasing demand for fuel. Besides, petroleum as a fuel also causes air pollution and the greenhouse effect (Chang, 2018; Wicakso et al. 2020). Thus, it is necessary to find other sources as alternative energy for transportation fuel.

The coal pyrolysis process is the conversion of coal into liquid fuel at atmospheric pressure. However, the coal pyrolysis process produces a low liquid oil yield. Jilkova et al. (2015) performed the pyrolysis of coal at $650{ }^{\circ} \mathrm{C}$ for 3 hours. The liquid oil product obtained is $5.03 \%$. Onay and Koca (2015) carried out the pyrolysis of lignite and obtained liquid oil product of $13.26 \%$. Meanwhile, Zhao et al. (2018) observed the pyrolysis of lignite in a bench scale fixed bed reactor at a temperature of $800{ }^{\circ} \mathrm{C}$ and obtained a liquid oil yield of $5.11 \%$. The gas and solid products still dominated the coal pyrolysis products.

The co-pyrolysis process of coal with other materials with a higher $\mathrm{H} / \mathrm{C}$ atom ratio can increase the yield of liquid products. Empty fruit bunch (EFB) is biomass with a higher H/C atom ratio compared to coal (Chang, 2018; Huang et al. 2019). The hydrogen produced from the rapid pyrolysis of biomass stabilizes large radical structures generated during the early stages of coal pyrolysis (Wang et al. 2020). Other researchers worked on the copyrolysis of coal and biomass. For example, Yilgin et al. (2010) observed co-pyrolysis of lignite and sugar beet pulp with a ratio of 50:50 at $600{ }^{\circ} \mathrm{C}$ and obtained a liquid oil yield of $28 \%$. Huang et al. (2019), who carried out the co-pyrolysis of bituminous coal and wheat straw with a weight ratio of $25: 75$ at a temperature of $600{ }^{\circ} \mathrm{C}$ and a pressure of $0.3 \mathrm{MPa}$ obtained a liquid oil yield of $18 \%$. These studies used untreated biomass as the raw material. Even though using high temperatures above $500{ }^{\circ} \mathrm{C}$, the yield of liquid oil obtained is low.

Calcium oxide $(\mathrm{CaO})$ is an alkaline earth metal used as a catalyst for biomass pyrolysis. Yu et al. (2014) studied $\mathrm{CaO}$ on the pyrolysis of sewage sludge under the microwave and found that $\mathrm{CaO}$ supports the production of hydrogen gas products. Chen et al. (2017) carried out fast pyrolysis of cotton stalk biomass using calcium oxide. The results showed that the acid compounds in the liquid oil decreased while the ketones and hydrocarbons increased. $\mathrm{CaO}$ also has a catalytic role in the coal pyrolysis and promotes the release of volatiles (Wang et al. 2020).

The co-pyrolysis of coal and EFB in this work was conducted using $\mathrm{CaO}$ as the catalyst. Before being used as raw material, the EFB was pre-treated with a mixed solution of $\mathrm{NaOH}$ and $\mathrm{H}_{2} \mathrm{O}_{2}$. This pre-treatment resulted

\footnotetext{
* Corresponding author: sunarno@lecturer.unri.ac.id
} 
in a significant decrease in the lignin content in the EFB and an increase in the yield of liquid oil at co-pyrolysis temperatures below $500^{\circ} \mathrm{C}$. The use of $\mathrm{CaO}$ catalyst in the co-pyrolysis of EFB and coal can reduce acid compounds in liquid oil and increase the calorific value of liquid oil. The objective of the research is to study the effects of pretreatment of EFB, ratio of EFB/coal, and concentration of $\mathrm{CaO}$ catalyst on the yield and composition of the liquid oil product.

\section{Materials and Methods}

\subsection{Raw Materials and Catalyst}

The raw materials were empty fruit bunch (EFB) and coal. EFB was obtained from PTPN V PKS Sei. Galuh, Riau Province, Indonesia, while the coal was obtained from Peranap, Indragiri Hulu Regency, Riau Province. The analyses of proximate and ultimate were done at the Central Laboratory of Coal and Geothermal Mineral Resources, Bandung, Indonesia, using TGA Q500IR and a LECO-932 elemental analyzer. The results of EFB and coal analysis are presented in Table 1. Calcium Oxide catalyst was commercial grade $(>95 \%)$ with particle sizes less than $50 \mu \mathrm{m}$. CaO catalyst was analyzed by BET (Brunaur, Emmet and Teller). Analysis of BET was done at Integrated Laboratory of Diponegoro University. The result of the $\mathrm{CaO}$ analysis is presented in Table 2 .

\subsection{Pre-treatment of Coal and EFB}

Pre-treatment of coal was carried out by washing with water. After that, it was dried under the sun for 6 hours to reduce the water content. The coal was crushed and sieved by 50 mesh standard screening. Finally, the coal was dried using an oven at $105^{\circ} \mathrm{C}$ for 24 hours. EFB from plantations was washed with water and dried in the sun. The dried EFB was cut at a range of $0.5-1 \mathrm{~cm}$ size. Fifty grams of EFB were mixed with $100 \mathrm{~mL}$ of $10 \%(\mathrm{w} / \mathrm{v}) \mathrm{NaOH}$ solution and $100 \mathrm{~mL}$ of $\mathrm{H}_{2} \mathrm{O}_{2}$ solution at $200 \mathrm{rpm}$ and $27^{\circ} \mathrm{C}$ for 48 hours.

Table 1

The Proximate and Ultimate analysis of EFB and coal

\begin{tabular}{clcc}
\hline Sample & & EFB & Coal \\
\hline Proximate & Volatile (\%) & 73.84 & 25.59 \\
& Fixed carbon (\%) & 13.5 & 29.25 \\
& Ash (\%) & 3.3 & 31.39 \\
& Moisture (\%) & 9.36 & 13.79 \\
& Heating value & 13.56 & 16.37 \\
& (MJ/kg) & & \\
& & & \\
Ultimate & Carbon (\%) & 47.54 & 60.36 \\
& Hydrogen (\%) & 7.11 & 3.1 \\
& Nitrogen (\%) & 0.62 & 0.17 \\
& Sulfur (\%) & - & 0.18 \\
& Oxygen (\%) & 39.82 & 36.19 \\
\hline
\end{tabular}

Table 2

The BET analysis of calcium oxide $(\mathrm{CaO})$

\begin{tabular}{cc}
\hline Element & Value \\
\hline Surface Area & $8.563 \mathrm{~m}^{2 / g}$ \\
Pore Size & $31.56 \AA$ \\
Total Pore Volume & $0.0135 \mathrm{cc} / \mathrm{g}$ \\
\hline
\end{tabular}

The concentration of $\mathrm{H}_{2} \mathrm{O}_{2}$ were varied at $0 \% ; 1 \% ; 2 \%$; $3 \%(\mathrm{v} / \mathrm{v})$. The treated EFB was filtered and washed with distilled water. Then, it was dried using an oven at $110^{\circ} \mathrm{C}$ for 24 hours. The treated EFB was subsequently analyzed for lignocellulosic content with Chesson-Datta Method and pyrolysis tested at $400{ }^{\circ} \mathrm{C}$ for one hour.

\subsection{Co-Pyrolysis Methods}

The co-pyrolysis was performed using the calcium oxide catalyst in a packed bed reactor. The schematic diagram of the co-pyrolysis apparatus is presented in Figure 1. This system consists of a tube reactor (inner diameter of $35 \mathrm{~mm}$ and length of $240 \mathrm{~mm}$ ), condenser, separator, temperature controller, nitrogen cylinder, and flowmeter. The treated EFB and the treated coal were mixed with a weight ratio of $(0: 100,75: 25,50: 50$, and 25:75). The mixed EFB and coal were fed into the packed bed reactor and heated at $400{ }^{\circ} \mathrm{C}$ as well as the nitrogen gas was flowed at a flow rate of 100 $\mathrm{mL} / \mathrm{min}$ for one hour. The experiment was repeated with the addition of a $\mathrm{CaO}$ catalyst. The mass ratio variables of $\mathrm{CaO}$ catalyst to raw materials were $3 \%, 6 \%$, and $9 \%$. The catalytic co-pyrolysis experiment was repeated with two replicates. The vapor produced was condensed in a partial condenser using water, while the liquid oil product was collected in the Erlenmeyer flask. The products of liquid oil and char were measured by weight. The liquid oil was stored in the sample bottle and tested to determine the chemical percentage of liquid oil.

\subsection{Products of Co-pyrolysis Analysis}

Liquid oil yield and char were measured by weighing the products separately. The percentage of liquid oil product compounds was tested using gas chromatography-mass spectroscopy (GC-MS/QP2010 SHIMADZU). Densities of liquid oil were determined using pycnometer bottles. Viscosities of liquid oil were tested using an Ostwald viscometer. The acidity of liquid oil was measured using a digital $\mathrm{pH}$ meter. The calorific value of liquid oil was determined by a bomb calorimeter (P.H Hilton C200 series). The yield of liquid oil, char, and gas calculation was done using equations 1,2 and 3 .

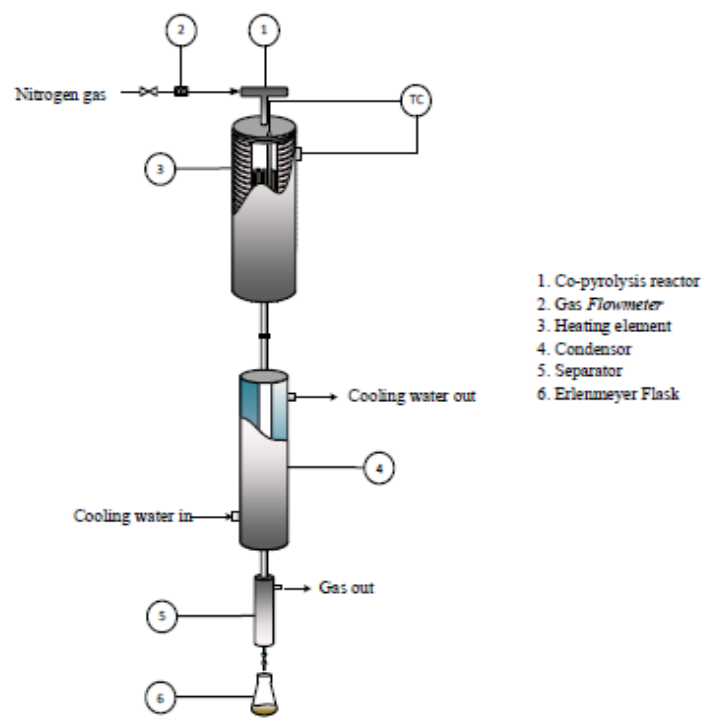

Fig. 1. The schematic of the co-pyrolysis apparatus 
$\mathrm{Y}_{\text {liquid oil }}=\frac{\mathrm{m}_{\text {liquid oil }}}{\mathrm{m}_{\text {feed }}} \times 100 \%$

$\mathrm{Y}_{\text {char }}=\frac{\mathrm{m}_{\text {char }}}{\mathrm{m}_{\text {feed }}} \times 100 \%$

$\mathrm{Y}_{\text {gas }}=\frac{\mathrm{m}_{\text {feed }}-\mathrm{m}_{\text {liquid oil }}-\mathrm{m}_{\text {char }}}{\mathrm{m}_{\text {feed }}} \times 100 \%$

Where $\mathrm{Y}_{\text {liquid oil }}$ is the product of liquid oil yield, mliquid oil is the mass of the liquid oil product, $\mathrm{m}_{\text {feed }}$ is the mass of reactor feed, $\mathrm{Y}_{\text {char }}$ is the char yield, $\mathrm{m}_{\text {char }}$ is the mass of char product, $\mathrm{Y}_{\text {gas }}$ is the product of gas yield.

\section{Results and Discussion}

\subsection{Analysis of the influence of $\mathrm{H}_{2} \mathrm{O}_{2}$ concentration and the $E F B$ biomass pre-treatment process on the yield of liquid oil}

Chemical pre-treatment was carried out using sodium hydroxide $(10 \% \mathrm{NaOH})$ with the addition of Hydrogen Peroxide $\left(\mathrm{H}_{2} \mathrm{O}_{2}\right)$ concentrations of $1 \%, 2 \%$, and $3 \%$. The results of the lignocellulose content of each EFB sample were analyzed using the Chesson method. The results can be seen in Fig. 2.

Fig. 2 shows that the pre-treatment decreases the EFB lignin levels. The lignin content in untreated EFB was $13.2 \%$. With the addition of $10 \% \mathrm{NaOH}$ and $3 \% \mathrm{H}_{2} \mathrm{O}_{2}$, the lignin content in EFB decreased to $11.4 \%$. Sodium hydroxide is able to break down the structure of lignin because the hydroxyl group in $\mathrm{NaOH}$ will decompose and bind to the constituents of lignin. These hydroxyl ions will accelerate the breaking of the bonds to the basic structure of lignin, so that the lignin will be dissolved more quickly or separated and dissolved from the EFB biomass. In order for the lignin dissolving process to be faster, the $\mathrm{H}_{2} \mathrm{O}_{2}$ compound was added. In addition, $\mathrm{NaOH}$ can also reduce hemicellulose content and increase cellulose content. According to Choi et al. 2013, $\mathrm{NaOH}$ pre-treatment of EFB was highly effective in removing lignin.

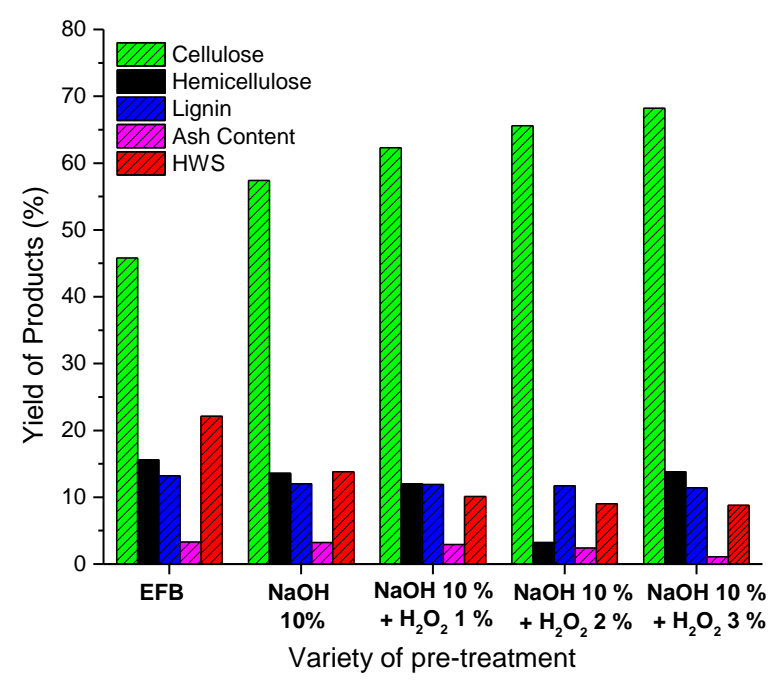

Fig. 2. Analysis of lignocellulose content in EFB using the Chesson method

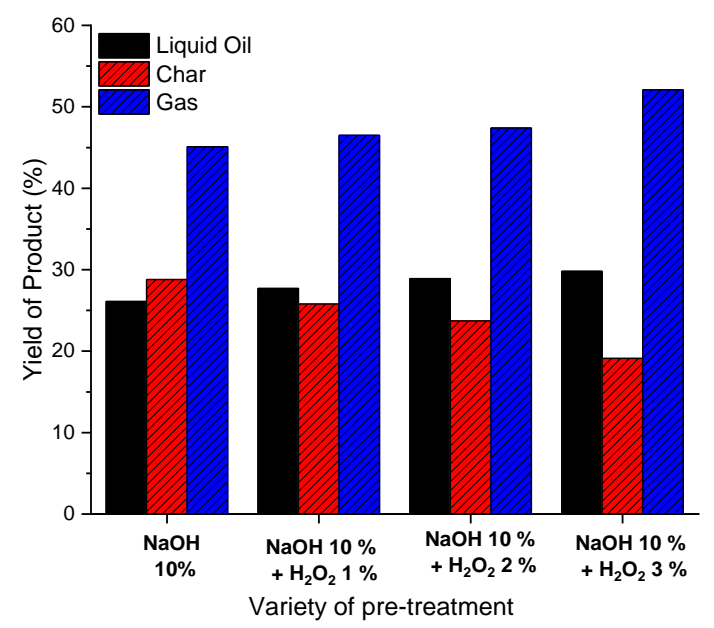

Fig. 3. The liquid oil yield based on EFB pre-treatment with $\mathrm{NaOH}$ and the addition of various concentration of $\mathrm{H}_{2} \mathrm{O}_{2}$

The addition of $\mathrm{H}_{2} \mathrm{O}_{2}$ helps in accelerating the degradation process. Hydrogen peroxide will act as a decomposition of the hydroxyl ions found in $\mathrm{NaOH}$ or a mixture of $\mathrm{NaOH}$ and EFB. The hydroxyl ions will bind to the basic structure of lignin so that lignin is more easily dissolved from EFB. Thus cellulose content in EFB increased (Gupta et al. 2010).

The effect of EFB pre-treatment with the addition of $\mathrm{NaOH}$ and $\mathrm{H}_{2} \mathrm{O}_{2}$ on the yield of liquid oil can be seen in Fig. 3. Pyrolysis of EFB with $10 \% \mathrm{NaOH}$ pre-treatment resulted in $26.1 \%$ liquid oil yield, while EFB with $10 \%$ $\mathrm{NaOH}$ and $3 \% \mathrm{H}_{2} \mathrm{O}_{2}$ pre-treatment produced $29.8 \%$ liquid oil yield.

Lignin levels significantly affect the yield of the liquid oil produced. If the lignin level is higher, the liquid oil will be less. It is inversely proportional to the char formed, the number will increase. The presence of lignin in biomass pyrolysis will lead to the charcoal production. Lignin is more difficult to decompose because of its decomposition over a wide temperature range, which is $160-900^{\circ} \mathrm{C}$, and the resulting high solid residue (Yang et al. 2007).

\subsection{The influence of empty fruit bunches (EFB) to coal ratio on the yield liquid oil}

The co-pyrolysis process was carried out using EFB pretreated using $10 \% \mathrm{NaOH}$ and $3 \% \mathrm{H}_{2} \mathrm{O}_{2}$. The co-pyrolysis process was carried out at an operating temperature of 400 ${ }^{\circ} \mathrm{C}$. The yield of liquid oil using variations in the ratio of raw materials can be seen in Fig. 4

Based on the data obtained, the char yield has decreased along with the enhancement in the blending ratio of $\mathrm{EFB}$ to coal. Meanwhile, the liquid oil yield increased. The reason is that with a higher biomass ratio, the availability of hydrogen during the co-pyrolysis process is getting bigger. Based on these results, there is a synergistic influence with the addition of EFB biomass. The hydrogen content in EFB can act as a hydrogen donor during the co-pyrolysis process. Hydrogen is useful for preventing cross-linking and recombination reactions from free radicals/metaplasts, which can increase char formation (Zhang et al. 2007). 


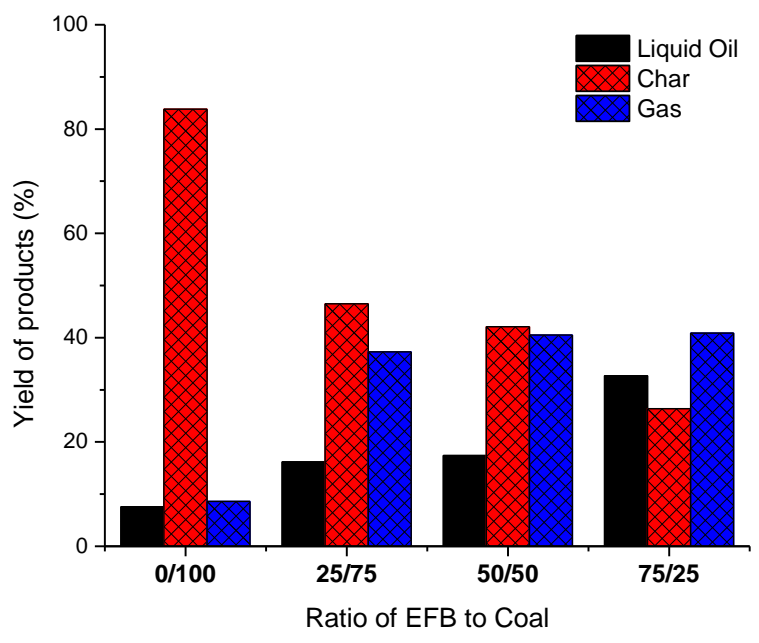

Fig. 4. Influence of the ratio of EFB to coal on the yield of liquid oil

Co-pyrolysis of EFB/coal with the ratio of $0 / 100$, there is a significant reduction in the liquid oil yield. This is because there is no hydrogen supply which can reduce the amount of liquid oil produced. In addition, coal has a volatile matter value of $25.59 \%$ lower than EFB, which has a volatile matter of $73.84 \%$. The yield of liquid oil has increased with the enhancement in the blending ratio between biomass and coal due to the high content of volatile matter contained in the biomass. This is in accordance with the research of $\mathrm{Li}$ et al. (2014), which states that tar and gas yields increase with the increase in the biomass blending ratio due to the high volatile matter in biomass. This study is also similar to Huang et al. (2019), who conducted co-pyrolysis of bituminous coal and wheat straw at a temperature of $600{ }^{\circ} \mathrm{C}$ and a pressure of $0.3 \mathrm{MPa}$. The results show that with an increase in the ratio of biomass/coal, the yield of liquid oil and gas increases while the yield of char decreases.

\subsection{The influence of the mass ratio of $\mathrm{CaO}$ catalyst to the raw materials on the yield of liquid oil}

The treated EFB (NaOH $\left.10 \%, \mathrm{H}_{2} \mathrm{O}_{2} 3 \%\right)$ to the coals ratio of $75 / 25$ was used to study the influence of co-pyrolysis using $\mathrm{CaO}$ catalyst and without catalyst on the yield of liquid oil. The varied mass ratio of $\mathrm{CaO}$ catalyst to raw materials were $3 \%, 6 \%$, and $9 \%$. Figure 5 shows that the increasing the percentage of $\mathrm{CaO}$ catalyst, the produced liquid oil increased. However, the co-pyrolysis process without a $\mathrm{CaO}$ catalyst resulted in more liquid oil yield than using a catalyst. In the co-pyrolysis process using $\mathrm{CaO}$, there is cracking of liquid oil into gas products. This happens because $\mathrm{CaO}$ acts as a catalyst that decreases the activation energy and increases the reaction rate so that the reaction rate is faster and the cracking of liquid oil occurs (Wang et al. 2020).

The reduction of liquid oil yield was also caused by the large number of non-condensable gas products that were formed. When the cracking process occurs, it produces more light hydrocarbon fractions that cannot be condensed. This type of hydrocarbon has a lower boiling point than the ambient temperature.

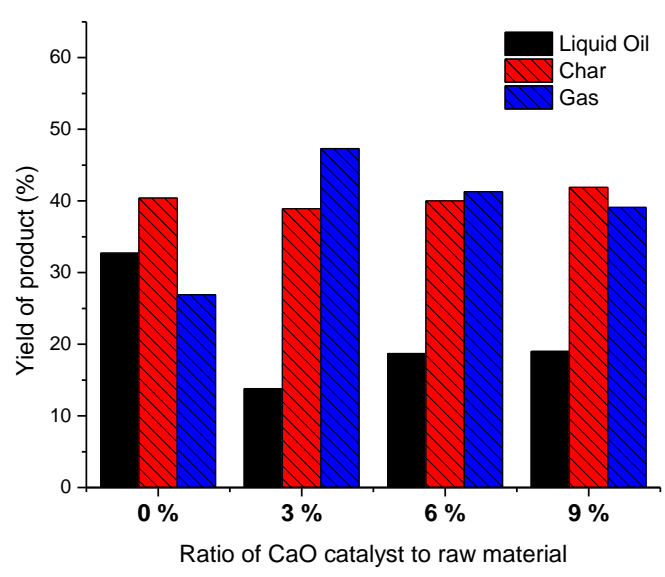

Fig. 5 Influence of ratio $\mathrm{CaO}$ catalyst/raw materials on the yield of liquid oil

The increase in the ratio of $\mathrm{CaO}$ catalyst to raw materials also affects the increase in the amount of char produced. According to Lin et al. (2010), it happens because $\mathrm{CaO}$ as a catalyst absorbs $\mathrm{CO}_{2}$ gas during the co-pyrolysis process. The more $\mathrm{CaO}$ catalyst used, the more $\mathrm{CO}_{2}$ gas will be absorbed. This causes char production in the copyrolysis process to increase while gas production decreases. $\mathrm{CaO}$ catalyst reacts with $\mathrm{CO}_{2}$ to form $\mathrm{CaCO}_{3}$, according to the equation below (Xu et al. 2018).

$$
\mathrm{CaO}_{(\mathrm{s})}+\mathrm{CO}_{2(\mathrm{~g})} \rightarrow \mathrm{CaCO}_{3(\mathrm{~S})}
$$

\subsection{Characteristic of liquid oil}

The characteristics of the liquid oil analyzed include physical and chemical characteristics. The analysis of physical characteristics was carried out for the liquid oil that had the highest yield of each variable, namely liquid oil from treated EFB with $\mathrm{NaOH} 10 \%$ and $\mathrm{H}_{2} \mathrm{O}_{2} 3 \%$, the treated $\mathrm{EFB} / \mathrm{coal}$ with a ratio of $75 / 25$, and the treated $\mathrm{EFB} /$ coal with a ratio of $75 / 25$ using $9 \% \mathrm{CaO}$ catalyst.

\subsubsection{Chemical characteristics of liquid oil}

Chemical characteristics were analyzed by gas chromatography-mass spectroscopy (GC-MS) to determine the chemical components contained in the liquid oil. Chromatogram of liquid oil can be seen in Fig 6 . Table 3 shows the composition of liquid oil products from treated $\mathrm{EFB}$ and $\mathrm{EFB} /$ coal $(\mathrm{R}=75 / 25)$ with a $9 \% \mathrm{CaO}$ catalyst. The liquid oil product from $\mathrm{EFB} /$ coals $(\mathrm{R}=75 / 25)$ with $9 \% \mathrm{CaO}$ catalyst showed that hydrocarbon compounds increased while acid and phenol compounds decreased compared to the liquid oil of treated EFB. The $\mathrm{CaO}$ catalyst can significantly reduce the formation of acid and phenol content. Acidic compounds decrease because, during the pyrolysis process, the $\mathrm{CaO}$ catalyst neutralizes the acid produced, called deacidification. Deacidification results in the breakdown of $\mathrm{O}$ atoms to turn into ketones and furans. Deacidification also impacts increasing the amount of hydrocarbons which is indicated by the increasing calorific value. Decreased phenol compounds can occur because of two possibilities, $\mathrm{CaO}$ can react with the acid functional groups in phenol, and $\mathrm{CaO}$ can catalyze the decomposition of phenol to produce CO (Wang et al. 2020). 


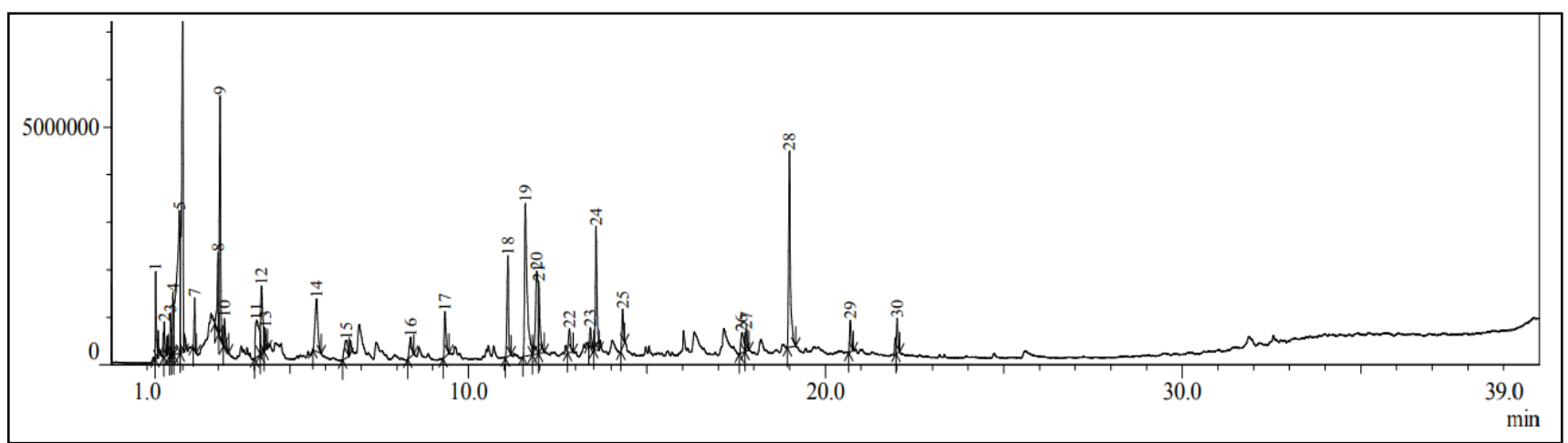

(a)

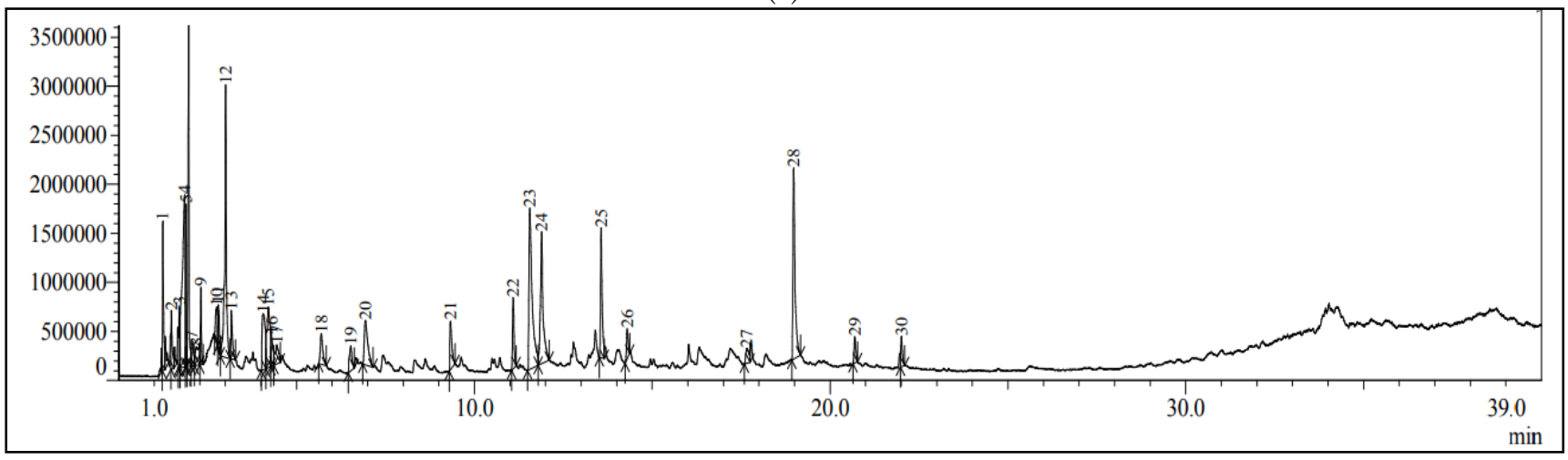

(b)

Fig. 6. Chromatogram of liquid oil : (a) treated EFB, (b) treated EFB/coal (R=75/25) with $9 \% \mathrm{CaO}$ catalyst

Table 3

Chemical characteristics of liquid oil

\begin{tabular}{ccc} 
& \multicolumn{2}{c}{ The samples } \\
\cline { 2 - 3 } Components & The treated EFB (\% Area) & EFB/Coals (R = 75/25) \\
& 3.42 & 4.64 \\
Hydrocarbons $\mathbf{9} \%$ CaO catalyst (\% Area) \\
Phenols & 26.69 & 22.84 \\
Acids & 14.87 & 11.96 \\
Ketones & 26.53 & 41.94 \\
Furans & 8.51 & 8.93 \\
Aldehydes & 2.86 & 1.39 \\
Eter and Ester & 17.12 & 8.30 \\
\hline
\end{tabular}

Table 4

Physical characteristic of liquid oil

\begin{tabular}{|c|c|c|c|c|c|}
\hline \multirow{2}{*}{ Parameter } & \multicolumn{3}{|c|}{ Liquid oil products from } & \multirow{2}{*}{$\begin{array}{c}\text { Bio-oil } \\
\text { standards } \\
\text { [Dynamotiv, } \\
2012]\end{array}$} & \multirow{2}{*}{$\begin{array}{l}\text { Diesel standards } \\
\text { [Pazylzhan et } \\
\text { al.2018] }\end{array}$} \\
\hline & $\begin{array}{c}\text { The treated } \\
\text { EFB }\end{array}$ & $\begin{array}{c}\text { Treated } \\
\text { EFB/Coals } \\
(\mathrm{R}=75 / 25)\end{array}$ & $\begin{array}{l}\text { Treated EFB/Coals (R } \\
=75 / 25) \text { using } \mathrm{CaO} 9 \%\end{array}$ & & \\
\hline Density (g/mL) & 1.009 & 1.029 & 1.032 & $0.9-1.2$ & 0.8512 \\
\hline Viscosity (cSt) & 2 & 2.1 & 2.19 & $4-7,8$ & $2.3-8$ \\
\hline $\begin{array}{l}\text { Heating value } \\
(\mathrm{MJ} / \mathrm{kg})\end{array}$ & 33.72 & 34.69 & 34.93 & $13-19$ & 42.75 \\
\hline $\mathrm{pH}$ & 1.9 & 2.1 & 2.4 & $2-3.3$ & 5 \\
\hline
\end{tabular}


Liquid oil is derived from hemicellulose, cellulose, and lignin decomposition. In general, the main liquid oil compounds identified are carboxylic acids, alcohols, ketones, aldehydes, ether, esters, phenols, and derivatives compounds (Lu et al. 2009). Hydrocarbons are resulted from the synergy and the thermal cracking of coal and biomass. Phenolic compounds are derived from the depolymerization of lignin contained in biomass. Ketone compounds are the product of condensation reactions from carbohydrate compound fractions and decomposition reactions of oxygenated compounds, such as saccharides and furans (Alvarez et al. 2019). The formation of these fatty acid ethyl esters and fatty alcohols indicates that there is the participation of biomass derivative radicals in the radical termination reaction (Sharypov et al. 2003).

\subsubsection{Physical characteristics of liquid oil}

The physical characteristics of the liquid oil analyzed are density, viscosity, heating value, and $\mathrm{pH}$. The analysis results are compared with the standard characteristics of bio-oil and diesel oil. This comparison is used to see opportunities the liquid oil produced as fuel. The results of liquid oil's physical characteristics can be seen in Table 4 .

The density of the liquid oil product was $1.032 \mathrm{~g} / \mathrm{mL}$, in the range of bio-oil standard values. The liquid oil density is influenced by the molecular weight of the compounds contained in the liquid oil. It tends to decrease when the co-pyrolysis temperature increases. This is due to the decomposition of a compound with a large molecular weight into a compound with a lower molecular weight due to the high temperature. The smaller the liquid oil density, the better it will be used as a fuel because it is lighter (Abnisa et al. 2011; Abnisa et al. 2013).

Viscosity is an important physical property of a fuel that must be considered when designing the storage, processing, and transportation of the fuel. In this study, the viscosity value of $2.19 \mathrm{cSt}$ was obtained. A low viscosity value indicates a high moisture content in the liquid oil. The viscosity of the liquid oil obtained decreased with increasing water content in the liquid oil. The water content in liquid oil comes from the moisture of the raw material and the dehydration reaction that occurs during the co-pyrolysis process (Sunarno et al. 2020).

The heating value of combustion shows the calorific energy contained in each mass unit of fuel. The calorific value in this study is $34.93 \mathrm{MJ} / \mathrm{kg}$. As a comparison, the calorific value of liquid oil is higher than the calorific value of product oil produced from the pyrolysis of spirulina platensis residue, which is $25.70 \mathrm{MJ} / \mathrm{kg}$ (Jamilatun et al. 2019). This calorific value is also above the bio-oil range but below diesel oil. This relatively low calorific value is due to the presence of oxygenate compounds contained in the liquid oil.

Table 4 shows the degree of acidity $(\mathrm{pH})$ of liquid oil resulting from this study of 2.4 which is in the standard of bio-oil acidity (pH) set by Dynamotive (Dynamotive, 2012), namely with a $\mathrm{pH}$ ranging from 2 - 3.3 but still below the standard of acidity $(\mathrm{pH})$ for diesel oil, which is around 5 . Liquid oil consists of carboxylic acid compounds such as acetic acid and formic acid, which cause liquid oil to be increasingly active acids with a $\mathrm{pH}$ between $2-3$.

This research has resulted in higher liquid oil yields than previous studies. However, the liquid oil products have a lower $\mathrm{pH}$ and calorific value than diesel oil. To improve the quality of liquid oil, future research will be carried out at temperatures above $400{ }^{\circ} \mathrm{C}$ and with the addition of $\mathrm{CaO}$ catalyst above $9 \%$.

\section{Conclusions}

The pre-treatment of EFB, the ratio of treated EFB to coal, and the addition of $\mathrm{CaO}$ catalyst affect the yield and composition of the product. Increasing the ratio of treated EFB to coal can increase liquid oil yield. The addition of a $\mathrm{CaO}$ catalyst can reduce acid compounds and increase the calorific value of liquid oil. The catalytic co-pyrolysis process with treated $\mathrm{EFB}$ to coal ratio of $75: 25$ at the temperature of $400{ }^{\circ} \mathrm{C}$ and addition $9 \% \mathrm{CaO}$ catalyst resulted in $19 \%$ liquid oil yield consisting of $4.64 \%$ hydrocarbon compounds, $22.84 \%$ phenols, $11.96 \%$ acids, $41.94 \%$ ketones, $8.93 \%$ furans, $1.39 \%$ aldehydes, and $8.3 \%$ esters with a heating value of $34.93 \mathrm{MJ} / \mathrm{kg}$, density of $1.032 \mathrm{~g} / \mathrm{mL}$, the viscosity of $2.19 \mathrm{cSt}$, and $\mathrm{pH}$ of 2.4 . The liquid oil can be considered as an alternative renewable energy source.

\section{References}

Abnisa, F., Daud, W.M.A., \& Sahu, J.N. (2011). Optimization and characterization studies on bio-oil production from palm shell by pyrolysis using response surface methodology. Biomass and Bioenergy, 35, 3604-3616. https://doi.org/10.1016/j.biombioe.2011.05.011

Abnisa, F., Daud, W.M.A., Ramalingam, S., Azemi, M.N.B.M., \& Sahu, J.N. (2013). Co-pyrolysis of palm shell and polystyrene waste mixtures to synthesis liquid fuel. Fuel, 108, 311-318. https://doi.org/10.1016/j.fuel.2013.02.013

Ali, A. \& Zhao, C. (2020). Direct liquefaction techniques on lignite coal: A review. Chinese Journal of Catalysis, 41, 375-389. https://doi.org/10.1016/S1872-2067(19)63492-3

Alvarez, J., Amutio, M., Lopez, G., Santamaria, L., Bilbao, J., \& Olazar, M. (2019). Improving bio-oil properties through the fast co-pyrolysis of lignocellulosic biomass and waste tyres. Waste Management, $\quad 85, \quad 385-395$. https://doi.org/10.1016/j.wasman.2019.01.003

Chang, S.H. (2018). Bio-oil derived from palm empty fruit bunches: Fast pyrolysis, liquefaction and future prospects. Biomass and Bioenergy, 119, 263-276. https://doi.org/10.1016/j.biombioe.2018.09.033

Chen, X., Chen, Y., Haiping, Y.H., Chen,W., Wang, X., \& Chen, H. (2017). Fast pyrolysis of cotton stalk biomass using calcium oxide. Bioresource Technology, 233, 15-20. https://doi.org/10.1016/j.biortech.2017.02.070

Choi, W.I., Park, J.Y., Lee, J.P., Oh, Y.K., Park, Y.C., Kim, J.S., Park, J.M., Kim, C.H., \& Lee, J. S. (2013). Optimization of $\mathrm{NaOH}$-catalyzed steam pretreatment of emptyafruitabunch. BiotechnologyaforaBiofuels, $\quad 6(170), \quad$ 1-8. https://doi.org/10.1186/1754-6834-6-170

Dynamotive. (2012). Product Information Booklet: Dynamotive Bio-oil Information Booklet. Dynamotive, Canada.

Gupta, R., \& Lee, Y.Y. (2010). Pretreatment of corn stover and hybrid poplar by sodium hydroxide and hydrogen peroxide. Biotechnology Progress, 26(4), 1180-1186. https://doi.org/10.1002/btpr.405

Huang,Y.,Wang, N., Liu, Q., Wang, W., \& Ma, X. (2019). Copyrolysis of bituminous coal and biomass in a pressured fluidized bed. Chinese Journal of Chemical Engineering, 27, 1666-1673. https://doi.org/10.1016/j.cjche.2019.03.012

Jamilatun, S., Budhijanto, R., \& Budiman, A. (2017). Thermal decomposition and kinetic studies of pyrolysis of spirulina platensis residue. International Journal of Renewable Energy Development, 6(3), 193-201. https://doi.org/10.14710/ijred.6.3.193-201 
Jamilatun, S., Budhijanto, R., Yuliestyan, A., Hadiyanto., \& Budiman, A., (2019). Comparative analysis between pyrolysis products of spirulina platensis biomass and its residues. International Journal of Renewable Energy Development, $\quad$ 8(2), 133-140. https://doi.org/10.14710/ijred.8.2.133-140

Júlková, L., Ciahotný, K., \& Kusý, J. (2015). Pyrolysis of brown coal using a catalyst based on W-Ni. Acta Polytechnica, 55(5), 319-323. https://doi.org/10.14311/AP.2015.55.0319

Li, S., Chen, X., Liu, A., Wang, L., \& Yu, G. (2014). Study on copyrolysis characteristics of rice straw and shenfu bituminous coal blends in a fixed bed reactor. Bioresource Technology, 155, 252-257.

Lin, Y., Zhang, C., Zhang, M., \& Zhang, J. (2010). Deoxygenation of bio-oil during pyrolysis of biomass in the presence of $\mathrm{CaO}$ in a fluidized-bed reactor. Energy Fuels, 24(10), 5686-5695.

Liu, C., Wang, H., Karim, A.M., Sun, J., \& Wang, Y. (2014). Catalytic fast pyrolysis of lignocellulosic biomass. Chemical Society Reviews, 43(22), 7594-7623.

Lu, Q., Li, W.Z., \& Zhu, X.F. (2009). Overview of fuel properties of biomass fast pyrolysis oils. Energy Conversion and Management, 50(5), 1376-1383.

Mushtaq, F., Mat, R. \& Ani, F.N. (2014). A review on microwave assisted pyrolysis of coal and biomass for fuel production. Renewable and Sustainable Energy Reviews, 39, 555-574.

Onay, O., \& Koca, H. (2015). Determination of synergetic effect in co-pyrolysis of lignite and waste tyre, Fuel, 150, 169-174. https://doi.org/10.1016/j.fuel.2015.02.041

Payormhorm, J., Kangvansaichol, K., Reubroycharoen, P., Kunchonthara, P., \& Hinchiranan, N. (2013). Pt/Al $\mathrm{Al}_{2} \mathrm{O}$ catalytic deoxygenation for upgrading of leucaena leucocephala-pyrolysis oil. Bioresource Technology, 139, 128135. https://doi.org/10.1016/j.biortech.2013.04.023

Pazylzhan, K., \& Wang, T. (2018). Difference analysis of combustion and emissions of $0 \#$ diesel,f-t diesel and biodiesel diesel. Journal of Advance Science and Technology, 12(2), 1325-1330.

Sharypov, V.I., Beregovtsova, N.G., Kuznetsov, B.N., Membrado, L., Cebolla, V.L., Marin, N., \& Weber, J.V. (2003). Copyrolysis of wood biomass and synthetic polymers mixtures. part iii: characterization of heavy products. Journal of Analytical and Applied Pyrolysis, 67, 325-340. https://doi.org/10.1016/S0165-2370(02)00071-2
Sunarno, Rochmadi, Mulyono, P., \& Budiman, A. (2018). Silicaalumina based catalytic cracking of bio-oil using double series reactor. International Journal of Renewable Energy Research, 8(1), 414-420. https://doi.org/10.20508/ijrer.v8i1

Sunarno, Saputra, E., Fermi, M.I., \& Utama, P.S. (2020). Noncatalytic co-pyrolysis of empty fruit bunch of palm and solid tire waste into upgrade bio-oil. International Journal of Renewable Energy Research, 10(2), 687-692. https://doi.org/10.20508/ijrer.v10i2

Wang, J., Ma, M., Bai, Y., Su, W., Song, X., \& Su, G. (2020). Effect of $\mathrm{CaO}$ additive on co-pyrolysis behavior of bituminous coal and cow dung. Fuel, 265, 1-6. https://doi.org/10.1016/j.fuel.2006.12.013

Wicakso, D.R., Nurandini, D., Mirwan, A., \& Putra, M.D. (2020). Integration of pyrolysis - tar decomposition over porous low grade iron ore. IOP Conference Series: Materials Science and Engineering, 722, 1-6. https://doi.org/10.1088/1757$899 \mathrm{X} / 722 / 1 / 012053$

Xu, A., Zhou, W., Zhang, X., Zhao, B., Chen, L., Sun, L., Ding, W., Yang, S., Guan, H. \& Bai, B. (2018). Gas production by catalytic pyrolysis of herb residues using $\mathrm{Ni} / \mathrm{CaO}$ catalysts. Journal of Analytical and Applied Pyrolysis, 130, 216-223

Yang, H., Yan, R., Chen, H., Lee, D. H., \& Zheng, C. (2007). Characteristics of hemicellulose, cellulose and lignin pyrolysis. Fuel. 86(12-13), 1781-1788. https://doi.org/10.1016/j.enconman.2009.12.010

Yllgin, M., Duranay, N.D., \& Pehlivan, D. (2010). Co-pyrolysis of lignite and sugar beet pulp. Energy Conversion and Management, $\quad 51, \quad 1060-1064$. https://doi.org/10.1016/j.enconman.2009.12.010

Yu, Y., Yu, J.Q., Sun, B, \& Yan, Z.Y. (2014). Influence of catalyst types on the microwave-induced pyrolysis of sewage sludge, Journal of Analytical and Applied Pyrolysis, 106, 86-91. https://doi.org/10.1016/j.jaap.2014.01.003

Zhang, L., Xu, L.P., Zhao, W., \& Liu, S. Q. (2007). Co-pyrolysis of biomass and coal in a free fall reactor. Fuel, 86(3), 353-359. https://doi.org/10.1016/j.fuel.2006.07.004

Zhao, H., Song, Q., Liu, S., Li, Y., Wang, X., \& Shu, X. (2018). Study on catalytic co-pyrolysis of physical mixture/staged pyrolysis characteristics of lignite and straw over an catalytic beds of char and its mechanism. Energy Conversion and Management, 161,13-26. https://doi.org/10.1016/j.enconman.2018.01.083 